\title{
Spatial and temporal variations in the occurrences of wet periods over major river basins in India
}

\author{
N R DEShPANDE* and N Singh \\ Indian Institute of Tropical Meteorology, Dr. Homi Bhabha Road, Pashan, Pune 411 008, India. \\ *e-mail: nrdesh@tropmet.res.in
}

\begin{abstract}
This study highlights the hydro-climatic features of the five wet periods contributing in different percentages to the annual rainfall total over major river basins in India. Spatial and temporal variations in the parameters such as starting date, duration and rainfall intensity of these wet periods throughout India have been discussed using daily gridded rainfall data for the period 1951-2007. An attempt is also made here, to assess the impact of global SSTs on the start and duration of the wet periods in Indian river basins.

It is observed that, for almost all river basins in India, the $10 \%$ wet period occurs in the months of July/August with an average duration of 1-3 days and rainfall intensity varying from 44 to $89 \mathrm{~mm} /$ day. The duration of the wet period contributing $90 \%$ to the annual rainfall varies from 112 days in the central parts of India to 186 days in the northern parts of the country. Significant increase in the rainfall intensity has been observed in the case of some river basins of central India. The late start of $75 \%$ wet period along the West Coast and in peninsular river basins has been observed with increase in Nino 3.4 SSTs (MAM), while increase in the duration of the $75 \%$ wet period over the Krishna basin is associated with increase in Nino 3.4 SSTs (concurrent JJAS).
\end{abstract}

\section{Introduction}

The Indian economy is still considered as agrarian and hence is dependent on the amount and spatiotemporal distribution of monsoon rainfall. As a result, onset of the monsoon and its subsequent progress over the country is a matter of great interest and anxiety to everyone, particularly, to the farmers, the hydrologists and the administrators. A large part of the agricultural production comes from the rain-fed crops (Kumar et al 2004). Good monsoon always means a good harvest and brings in cheer all around. A weak or bad monsoon is always considered as a big set back to India's economy and always results in decrease in the country's GDP levels (Gadgil and Gadgil 2004). Except where irrigation is available, planting is restricted to the beginning of the wet season. Crops suffer most from a late or weak start of the rainy season and could be considerably affected during the extended breaks in monsoon rains. Also, if the southwest monsoon withdraws from a region earlier than expected, late planted crops may be damaged during the filling stages due to lack of moisture. A late withdrawal or late-season rains, are on the other hand considered detrimental to maturing crops. Planning is especially critical in monsoon regions which experience distinct wet and dry seasons. To ensure sustainable agriculture in a region, knowledge of the local climate especially about the rainfall features is vital.

In various parts of India, summer monsoon season is the principal rainy season contributing nearly $75-90 \%$ to the annual total. The contribution of the monsoon rainfall to the annual total, however, varies widely at different places, from $10 \%$ in Pamban (Tamil Nadu) to 95\% in Rajasthan. Monsoon rain sets in over Kerala around 1 June, progresses northeastward, northward, northwestward and finally covers the entire country in about

Keywords. River basin; wet period; starting date; duration; rainfall intensity; linear trend. 
45 days (Ananthakrishnan and Soman 1988). The monsoon starts retreating from northwest India by 1 September and from south peninsula by middle of October. During the monsoon season some parts receive very heavy rainfall and experience floods while others are devoid of rainfall and suffer from droughts. Monsoon rainfall shows large variations both on temporal scale as well as on spatial scale. Besides the south-west monsoon season, north-east monsoon season in Tamil Nadu and western disturbances over Jammu and Kashmir also contribute substantially to the annual total. Thunderstorm activities in the pre-monsoon period also contribute considerably at many places. Such non-monsoonal rain spells are important in agricultural management and to understand the interannual variations of the regional rainfall and its teleconnections with other global phenomena such as ENSO (Goswami and Xavier 2005).

Many studies are available on the onset and withdrawal of rainy season in different parts of the world. Some of them are based on outgoing longwave radiation (OLR) data (Kousky 1988; Wang 1994). Higgins et al (1997) used raingauge data to define summer monsoon onset over the southwestern United States. Qian and Yang (2000) examined the regional features of summer monsoon components over South China Sea. They used various datasets including satellite measurements to understand the onset, maintenance, and retreat of monsoon. Marengo et al (2001) used a combination of raingauge data and OLR data to define monsoon onset and withdrawal over South America. Odekunle $(2004,2006)$ used rainfall data, to study rainy season onset and retreat over Nigeria. Klein Tank et al (2006) found significant positive trends in the precipitation amount on very wet days (crossing 95th percentile of the distribution) at many places in India. Further, he mentioned that indices representating the start and end of the wet season may be more appropriate for impact assessment studies of climate change.

There have been extensive studies on the summer monsoon season in India but studies relating to start and cessation of the entire rainy season or heavy rain spells are very few. Ojective criteria for defining the duration of rainy season are also lacking. Similarly, no unified definition is available for withdrawal of monsoon season in India. A different approach, to define start and end of the rainy period and its duration, is used in the present study. Wet periods contributing 10, 25, 50, 75 and $90 \%$ to the annual rainfall total are considered and characteristic features such as start, end, duration and intensity of rainfall of these wet periods have been analysed.
The association between SSTs in the Pacific Ocean and Indian summer monsoon rainfall (ISMR) has been known for a long time (Flohn and Fleer 1975; Sikka 1980; Angell 1981; Rasmusson and Carpenter 1983). There is established evidence that the warm (cold) SSTs over central and east Pacific Ocean are associated with a deficient (excess) ISMR. ISMR is associated with the SSTs over other ocean basins also. Joseph and Pillai (1984) and Rao and Goswami (1988) observed warm (cold) SSTs over parts of the Arabian Sea during pre-monsoon months prior to an excess (deficient) ISMR. Kumar et al (1999) used the 140-year historical record of Indian summer monsoon rainfall and showed that the inverse relationship between the El Niño-Southern Oscillation (ENSO) and the Indian summer monsoon (weak monsoon arising from warm ENSO event) has broken down in recent decades. Saji et al (1999) and Ashok et al (2001) examined the relationship between Indian Ocean Dipole (IOD) mode and Indian summer monsoon rainfall. Recently, Ashok and Saji (2007) studied the relative impacts of the ENSO and Indian Ocean Dipole (IOD) events on Indian summer monsoon rainfall (JuneSeptember) at subregional scales. It is shown that the ENSO (IOD) index is negatively (positively) correlated with summer monsoon rainfall over seven (four) of the eight homogeneous rainfall zones of India. In general, the magnitude of ENSOrelated correlations is greater than those related to the IOD. Rao (1997) statistically linked basin scale rainfall over the Godavari basin with Southern Oscillation Index (SOI). A review of the research work on hydroclimatic teleconnections between hydrologic variables and large scale atmospheric circulation parameters related to tropical Pacific SSTs and Indian Ocean, in the Indian context, has been presented by Maity et al (2007). The potential associated with global SSTs, to anticipate fluctuations in the parameters of the wet periods have important implications for managing the water resources in different river basins of India. An attempt has been made here to assess the impact of SSTs on the occurrences of the wet periods as defined in the study, over the selected eight major river basins in India.

The present study has been undertaken with the following two main objectives:

- To document important statistical properties of the parameters of wet periods such as starting date, ending date, duration and rainfall intensity of the five wet periods $(10,25,50,75$ and $90 \%)$ over the selected eight major river basins and to examine temporal variations in the parameters (starting date, duration and rainfall intensity) of the five wet periods over these river basins. 


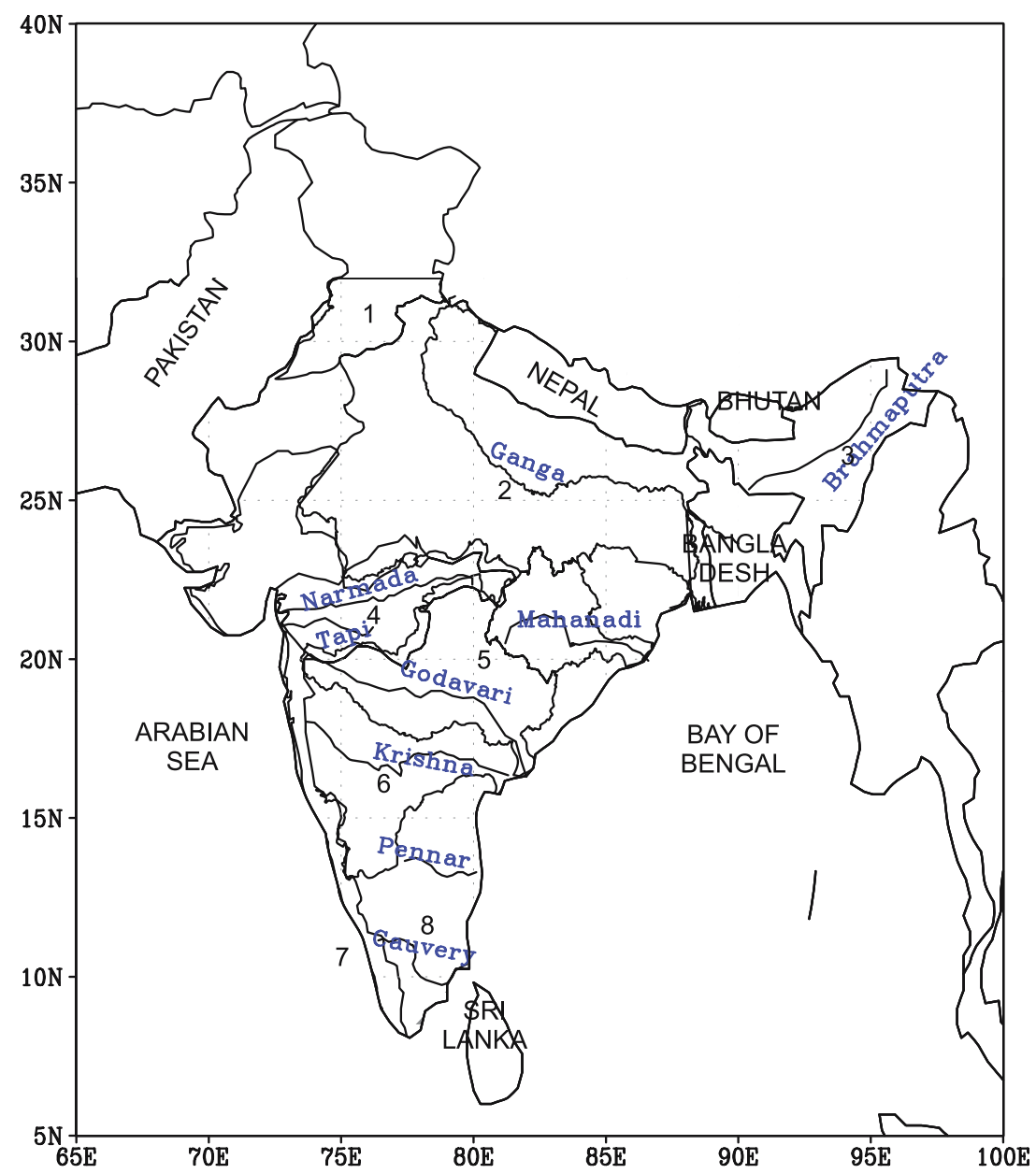

Figure 1. Eight river systems in India (with main river channels) used in the study.

- To study the impact of global SSTs on the occurrences of the wet periods.

\section{Study area}

Eight major river basins with well-defined drainage pattern and covering about $80 \%$ of the geographical area of the country are selected for the analysis on the basis of rainfall characteristics, origin of the river and the sea where it flows into. These eight river basins, along with the main river channels, are shown in figure 1 . The Indus basin restricted to south of $32^{\circ} \mathrm{N}$ has been examined considering the representation of stations appearing in the gridded dataset. These river basins are listed below and a brief description about their physiographic features is also given:

- Indus river basin (south of $32^{\circ} \mathrm{N}$ )

- Ganga river basin

- Brahmaputra and Barak river basins

- Narmada-Tapi river basins

- Godavari-Mahanadi river basins

- Krishna river basin
- West Coast river basins and

- peninsular river basins excluding the Godavari and Krishna river basins.

\subsection{Indus river basin}

The Indus originates in the northern slopes of the Kailash range in Tibet near the Manasarovar Lake. It enters Indian territory in Jammu and Kashmir. It has a large number of tributaries in both India and Pakistan and has a total length of about $2897 \mathrm{~km}$ from the source to the point near Karachi where it flows into the Arabian Sea. Total basin area in India is $321,289 \mathrm{~km}^{2}$. The main tributaries of the Indus, in India, are Jhelum, Chenab, Ravi, Beas and Sutlej. Only southern part of the basin comprising the area from Sutlej and Beas river basins covering the area of $121,275 \mathrm{~km}^{2}$ has been considered in the present study.

\subsection{Ganges river basin}

The Ganga originates at Gangotri glacier in Himalaya. The length of the Ganga is over $2500 \mathrm{~km}$. 
It is the largest river basin in India. Total basin area is $861,404 \mathrm{~km}^{2}$, comprising the area from eight states of India. The important tributaries of the river Ganga are Yamuna, Chambal, Ramganga, Gandak, Gomati, etc. It flows into the Bay of Bengal.

\subsection{Bramhaputra and Barak river basins}

The Brahmaputra originates in the Manasarovar Lake, which is also the source of the Indus and its tributary, the Sutlej river. Most of its course lies outside India. It flows eastward, parallel to the Himalayas and enters India in Arunachal Pradesh. This basin occupies the area in Arunachal Pradesh and Assam in India. The Subansiri, the Siang and the Debang are the main tributaries of the Brahmaputra river. The Barak river, the head stream of Meghna rises in the hills of Manipur (India) at an elevation about $2900 \mathrm{~m}$ and receives the combined flow of Ganga and Brahmaputra at Chandpur in Bangladesh. Finally it flows into Bay of Bengal. Total basin area of both rivers is $258,008 \mathrm{~km}^{2}$.

\subsection{Narmada-Tapi river basins}

The Narmada is a river in central India, having a length of $1289 \mathrm{~km}$. It rises on the Amarkantak hill in Madhya Pradesh state. Its main tributaries are Kolar, Bama, Hire, Tawa and Burhner. The Tapi is, also, a river of central India in the eastern Satpura range in southern Madhya Pradesh state. The principal tributaries of Tapi river are Purna, Girna, Panzara, Waghur, Bori and Aner rivers. Total basin area of both these rivers is $162,940 \mathrm{~km}^{2}$. Both the Narmada and Tapi rivers flow in eastwest direction and flows into the Arabian Sea.

\subsection{Godavari and Mahanadi river basins}

The Godavari is the second largest river in India. The river is about $1450 \mathrm{~km}$ long. It rises near Nasik in Maharashtra and flows in the southeast direction across south-central India and empties into the Bay of Bengal. Some of its tributaries include Indravati, Manjira, Bindusara and Sarbari. The Mahanadi is a river of eastern India. It rises in the Satpura range of central India, and flows east to the Bay of Bengal. Brahmani is its main tributary. Total area of both these river basins is $454,491 \mathrm{~km}^{2}$.

\subsection{Krishna river basin}

The Krishna is one of the longest rivers in peninsular India (about $1300 \mathrm{~km}$ in length). It originates at Mahabaleshwar in Maharashtra, passes through Maharashtra, Karnataka and Andhra Pradesh before meeting Bay of Bengal. Its important tributaries are the Tungabhadra, the Koyna, the Bhima, the Malprabha, etc. Total basin area of the Krishna river is $258,945 \mathrm{~km}^{2}$.

\subsection{West Coast river basins}

Rivers originating in Western Ghats and flowing westward are small and flow fast because of the hilly nature of the terrain and the shorter distance between the mountain and the sea. Such rivers are located in Maharashtra, Karnataka and Kerala states of India. Some smaller rivers, like the Mandvi, the Kumbala, and the Bekal have separate watersheds, and drain into the Arabian Sea through the channel of the backwaters. Total area of these river basins is $117,962 \mathrm{~km}^{2}$.

\subsection{Peninsular river basins (excluding the Godavari and Krishna river basins)}

The peninsular rivers are relatively small in extent. They include the rivers from peninsular India, originating in the Western Ghats and flowing eastward and meeting Bay of Bengal. The Pennar and the Cauvery are important rivers in peninsular India. Pennar rises in the Chennakesava Hills of Karnataka and flows for $597 \mathrm{~km}$ before it falls into the Bay of Bengal. The source of river Cauvery is Talakaveri located in the Western Ghats. Its main tributaries are Shimsa, Hemavati, Kabini, Lokapavani, Bhavani, Noyyal and Amaravati. Total area of these river basins is $275,835 \mathrm{~km}^{2}$.

\section{Data used and methodology}

Daily gridded rainfall dataset for the period of 57 years (1951-2007) with the resolution of $1^{\circ} \times 1^{\circ}$, providing almost complete coverage of contiguous geographical area of India $\left(\sim 3.3\right.$ million $\left.\mathrm{km}^{2}\right)$, has been used for the analysis of wet periods. The dataset has been developed by India Meteorological Department (IMD), India (Rajeevan et al 2008). For the impact assessment studies of global SSTs on the occurrences of wet periods, monthly SST dataset for the period of 1951-2007 with the resolution of $1^{\circ} \times 1^{\circ}$, derived from HADISST 1.1 climatology dataset has been considered (Rayner et al 2003, website: badc/nerc.ac.uk/data/hadisst).

Wet periods or rainy periods are defined as the periods of the shortest duration in a year that contribute a specified percentage of rainfall to the anuual rainfall total of that year (Singh et al 1989). Yearwise, five wet periods of the shortest duration contributing $10,25,50,75$ and $90 \%$ to that year's rainfall total, have been picked up first for each of 

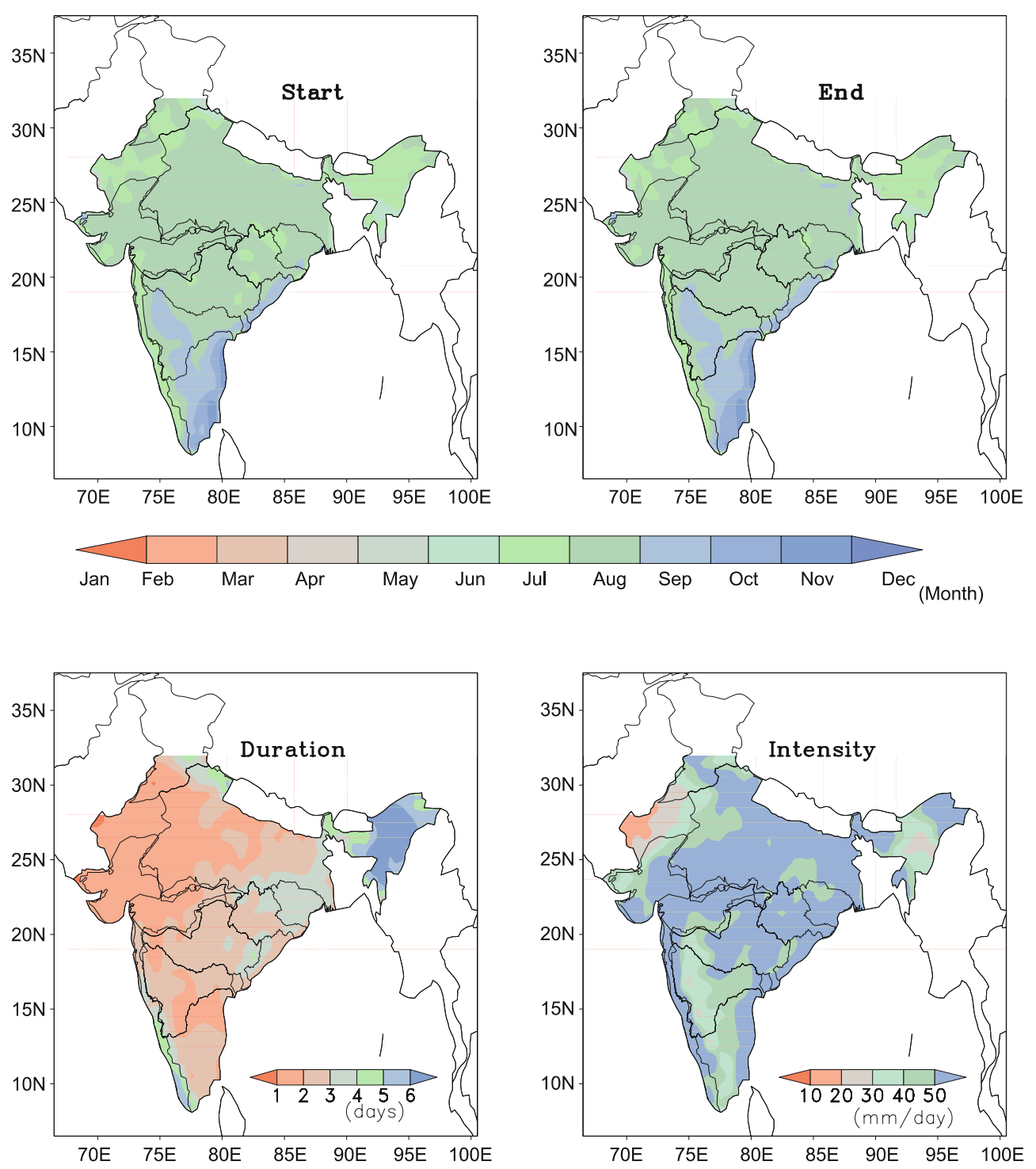

Figure 2(a). Parameters of $10 \%$ wet period.

the grids in India. Time series of 57 years has been prepared for starting day, ending day, duration and the intensity of rainfall of five wet periods at each grid. Climatology and temporal changes in these parameters (starting date, ending date, duration and rainfall intensity) of the five wet periods over major river basins have been studied.

\section{Results and discussions}

\subsection{Climatological features and temporal variations in the parameters of wet periods}

For deriving the climatological features of these parameters, simple average of the respective parameteric value has been taken over the period of 57 years of data for each grid. These climatological features are then displayed on the map of India using the software GrADS (version 1.8). Demarcation of selected river basins has also been shown on the same maps. Spatial patterns of the parameters such as start, end, duration and rainfall intensity of the five wet periods are shown in figure $2(\mathrm{a}-\mathrm{e})$. Table 1 gives the spatial averages of the parameters (start, duration and rainfall intensity) of the five wet periods for the selected eight river basins. It summarizes the information on statistical properties such as mean and coefficient of variation of these parameters.

To study the temporal changes in the parameters of the wet periods over the selected eight river basins, spatial averages of the parameters of the wet periods are taken over the set of grid points lying inside each of the selected river basin area and then time series of these spatially averaged parameters of five wet periods are plotted. These time series plots of eight river basins are 

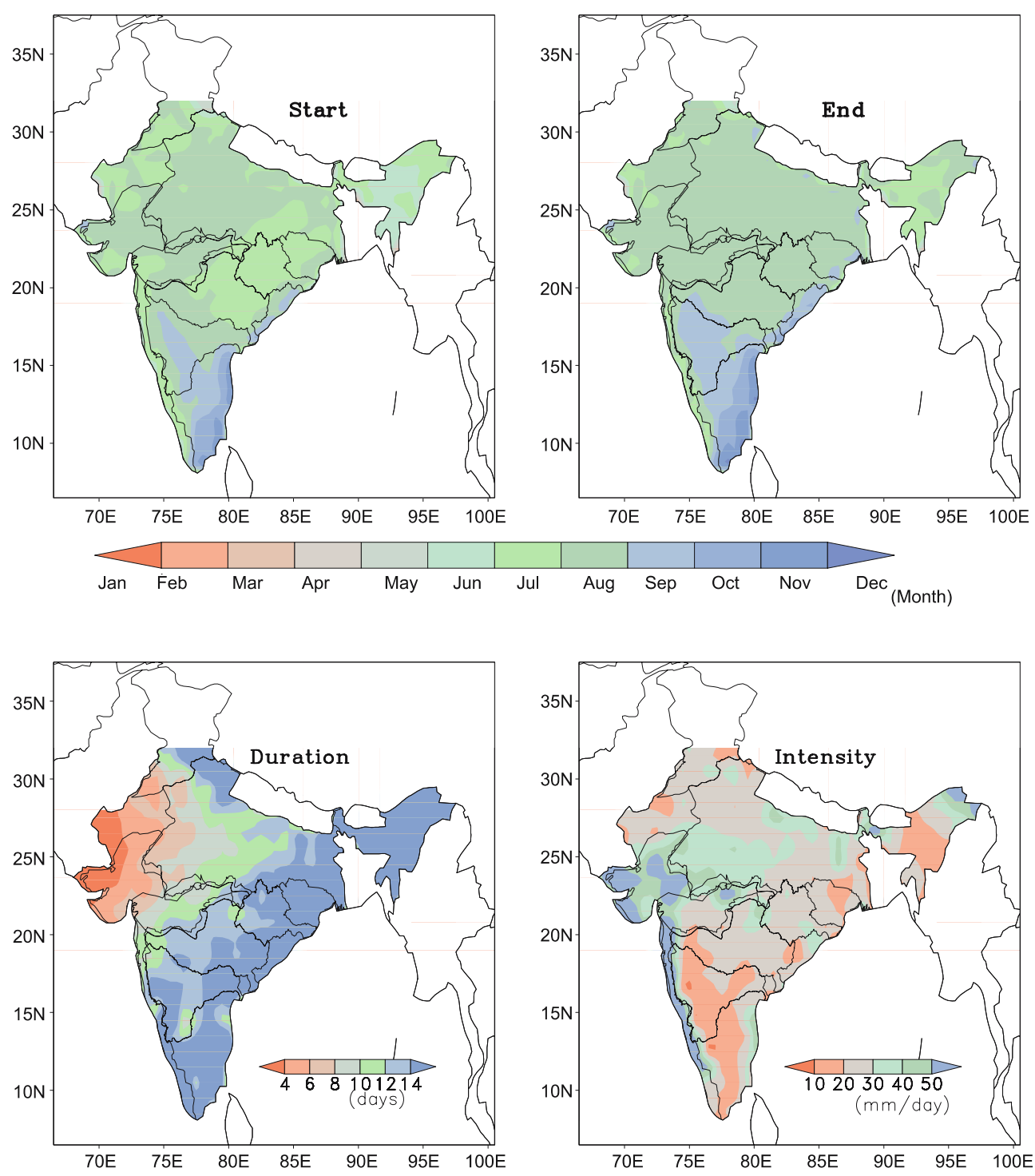

Figure 2(b). Parameters of $25 \%$ wet period.

shown in figures $3(\mathrm{a}-\mathrm{h})$. Fitted trend lines have also been shown in these figures. Significant trend has been marked with ' $*$ ' in right hand corner of the corresponding figure.

The climatological features of five wet periods and their temporal variations in eight river basins have been discussed in the following sections.

\subsubsection{Indus river basin (south of $32^{\circ} \mathrm{N}$ )}

The most distinctive characteristic of rainfall occurrences over this region, is the largest variability in the parameters of the wet period compared to all other river basins in India. On an average, 1 or 2 days are sufficient for $10 \%$ contribution to the annual rainfall when intensity of rainfall is of the order of $38 \mathrm{~mm} /$ day. The $25 \%$ wet period normally starts in the mid of July. The intensity of rainfall is $3-5 \mathrm{~mm} /$ day for 75 and $90 \%$ wet periods which is smaller compared to all other river basins. The $90 \%$ wet period starts at the end of March in the southern parts of Indus basin. Duration of the $90 \%$ period is the largest (i.e., 186 days) compared to all other river basins except peninsular river basins.

Significant decreasing trends have been noticed from figure 3(a), for the starting date of $75 \%$ wet periods indicating early occurrence, while significant increasing trends are seen for the durations of 25 and $50 \%$ wet periods resulting into significant decrease in the intensity of rainfall during these wet periods.

\subsubsection{Ganga river basin}

The $10 \%$ wet period generally occurs in the months of July-August. Just 1-3 days are sufficient for $10 \%$ contribution to the annual rainfall. Duration of $25 \%$ wet period is around 11 days. The 

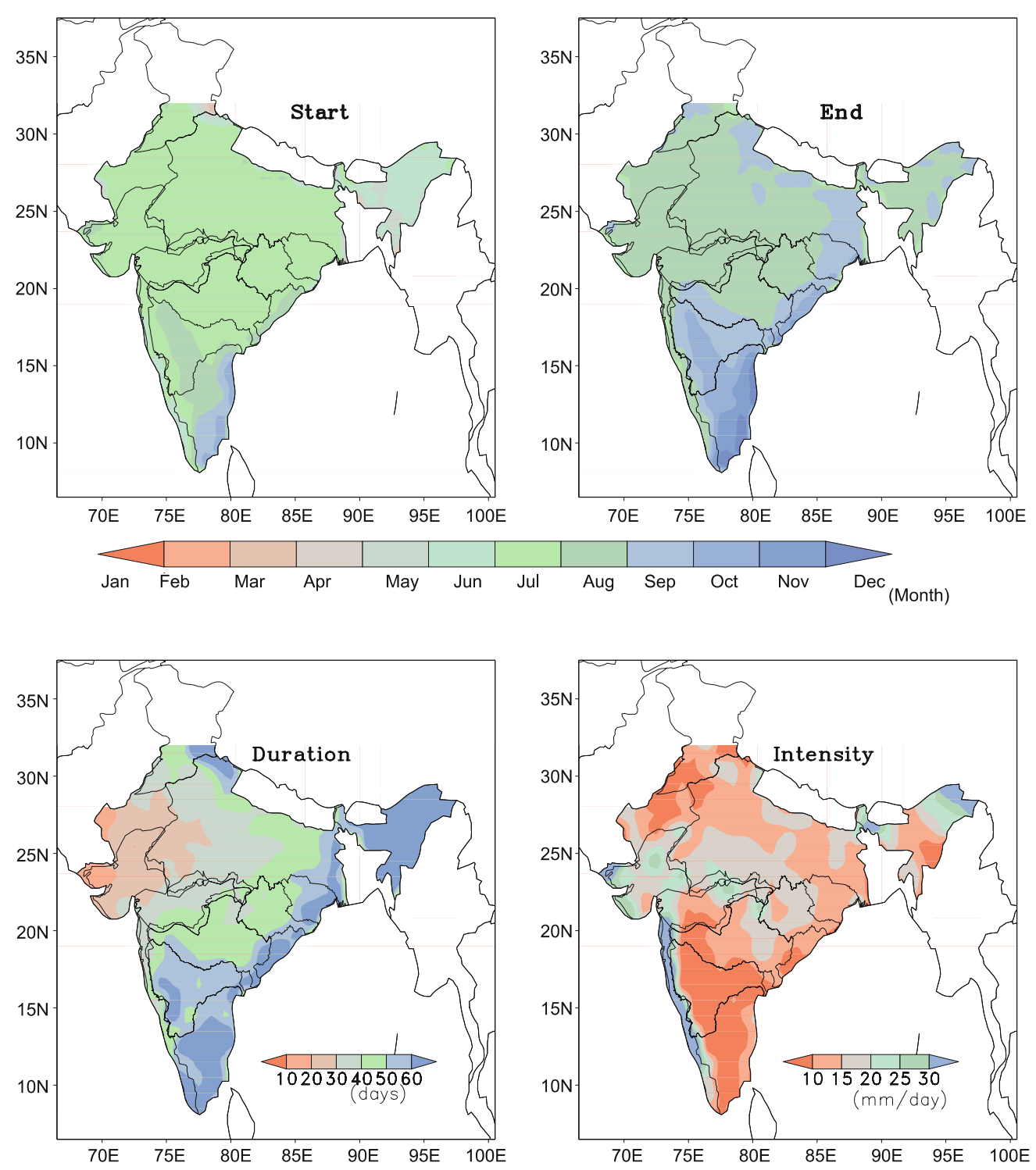

Figure 2(c). Parameters of $50 \%$ wet period.

duration of 50\% ranges from 30-60 days. Rainfall intensity of $75 \%$ wet period increases from less than $10 \mathrm{~mm} /$ day in the western parts of the basin to $10-15 \mathrm{~mm} /$ day in the eastern parts of the Ganga basin. The $90 \%$ wet period starts in the month of June. Rainfall intensity decreases from $60 \mathrm{~mm} /$ day during $10 \%$ period to $8 \mathrm{~mm} /$ day for $90 \%$ period. Active monsoon conditions characterized by intense monsoon trough over Indo-Gangetic Plains and westward/northwestward moving monsoon depressions/storms from Bay of Bengal give rise to heavy-to-very heavy rainfall over the Ganga basin.

From figure 3(b), it is seen that start of any wet period is occurring earlier in recent years. The change is significant for $75 \%$ wet period. No significant change has been noticed for any other parameters of the wet periods.

\subsubsection{Brahmaputra basin}

The $10 \%$ wet period generally occurs in the month of July. Duration of $10 \%$ wet period is around 6 days which is maximum compared to other river basins. The intensity of rainfall is comparable to that of West Coast river basins. For the Brahmaputra river basin, $75 \%$ wet period starts in the month of May. Duration of $90 \%$ period is quite large, i.e., of 184 days and it starts around April as pre-monsoon activity or thunderstorm activities contribute substantially to the annual rainfall. Rainfall activities continue till the end of October. Varability in all the parameters is low as seen from the coefficient of variation values especially for $90 \%$ wet period. Rainfall intensity decreases from $52 \mathrm{~mm} /$ day in $10 \%$ wet period to $12 \mathrm{~mm} /$ day in $90 \%$ wet period. 

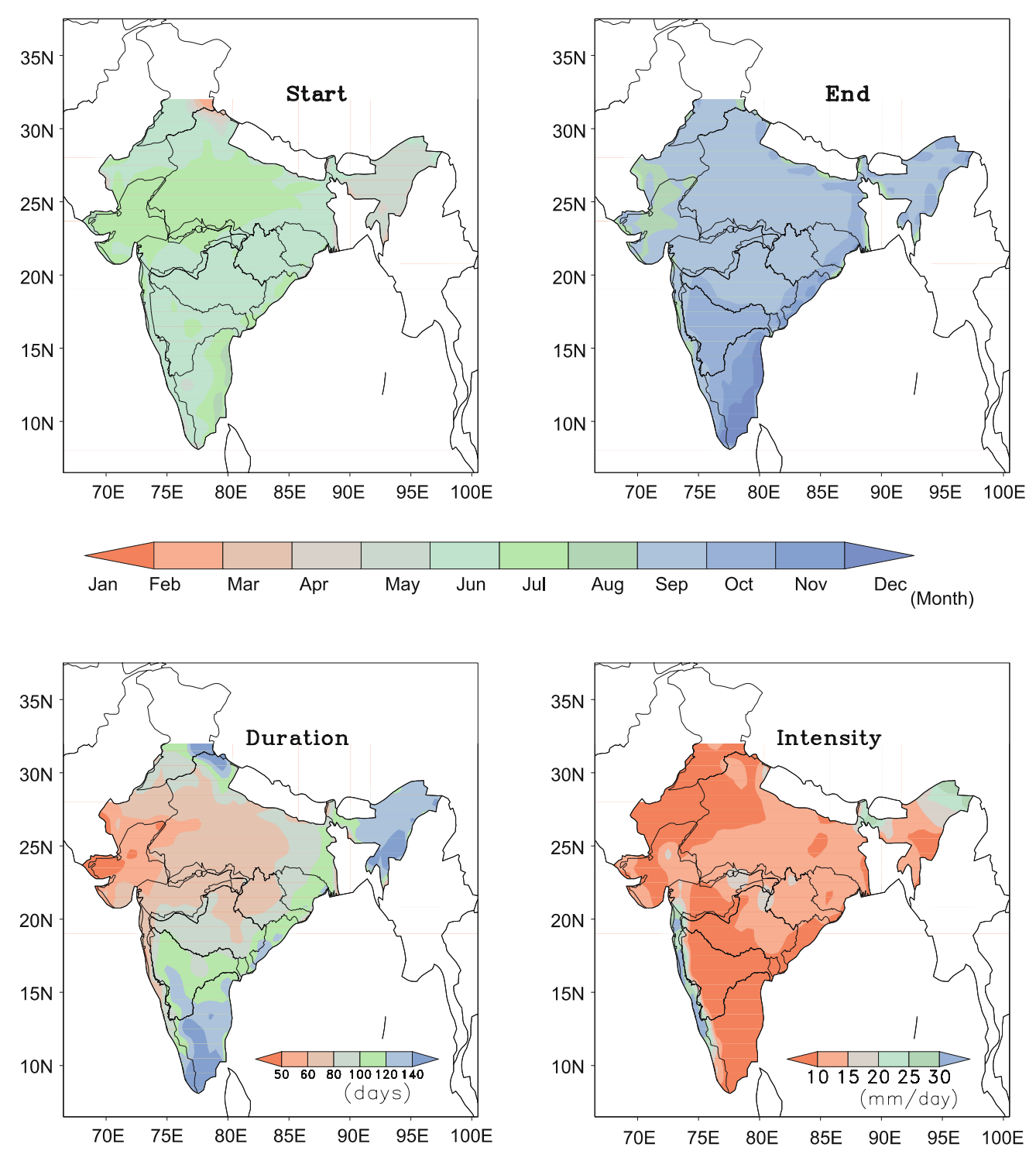

Figure 2(d). Parameters of $75 \%$ wet period.

No significant change has been observed in the case of any parameters of the wet periods (except for rainfall intensity of $25 \%$ wet period) in the Brahmaputra basin as seen from figure 3(c).

\subsubsection{Narmada-Tapi river basins}

The $10 \%$ wet period generally occurs in the month of August. The average duration of $10 \%$ wet period is just for 1 day which is shorter compared to rest of the river basins and its intensity is high, of the order of $65 \mathrm{~mm} /$ day which is next to that of West Coast river basins. Intense summer monsoon circulation is the main source of rainfall over the river basin. The $90 \%$ period starts around mid of June and 112 days are required to contribute this amount. Intensity of rainfall decreases from $65 \mathrm{~mm} /$ day for $10 \%$ period to $9 \mathrm{~mm} /$ day for $90 \%$ period.
Significant decreasing trend in the starting date of $10 \%$ wet period has been noticed indicating early occurrence of intense rain spells in the recent years. Decreasing trends in the durations of the intense periods (10 and 25\%) and significant increase in the intensity of these wet periods are also noticed. No significant change in rest of the parameters of the wet periods (figure $3 \mathrm{~d}$ ).

\subsubsection{Godavari-Mahanadi river basins}

The $10 \%$ wet period generally occurs in the month of August with average duration of 2 days. Wet period, contributing $50 \%$ to annual, starts in July. The duration ranges from 30-60 days within the basin. Intense monsoon circulation is the main source of rainfall over the Godavari-Mahanadi river basins and receives heavy-to-very heavy rainfall when monsoon depressions from Bay of Bengal 

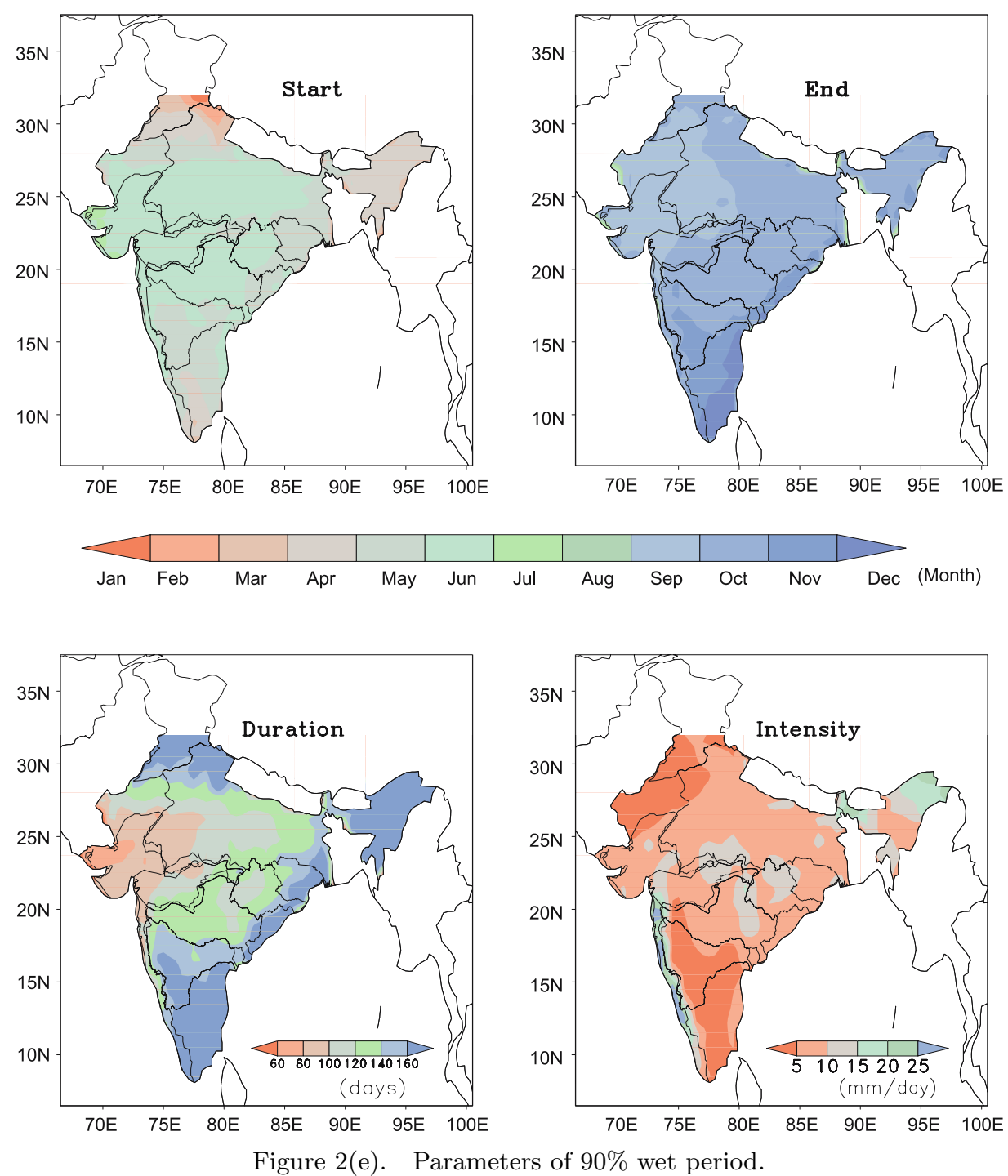

move northwestward slightly south of their normal track. These river basins are typical examples of representing the characteristics of India as a whole.

No significant change in the parameters of the wet periods over the Godavari-Mahanadi river basins has been noticed from figure 3(e), except significant increase in the rainfall intensity of intense rainfall period (10 and 25\%) has been observed.

\subsubsection{Krishna river basin}

The $10 \%$ wet period generally occurs at the end of August. Average duration is of 2 days. Intensity of rainfall is less during all the wet periods (except 90\%), compared to all other river basins as its central portion is located in the rainshadow area of the Western Ghats. All the wet periods over the basin start at a later period compared to all the river basins except river basins from peninsular India. Duration of the $90 \%$ period is quite large
(152 days), same as in the case of Indus, Brahmaputra and peninsular India. Intensity of rainfall in this period is around $5 \mathrm{~mm} /$ day, which is the same as that of Indus and peninsular river basins. Besides thunderstorms and summer monsoon, the basin marginally gets rainfall from northeast monsoon circulation.

In the case of the Krishna basin, none of the parameters of any wet period show significant longterm change except intensity of $10 \%$ wet period (figure 3f).

\subsubsection{West Coast river basins}

The $10 \%$ wet period generally occurs in the month of July. On an average, 3 days are required to contribute $10 \%$ of the annual rainfall. Rainfall intensity is maximum for all the wet periods ranging from $22 \mathrm{~mm} /$ day in $90 \%$ wet period to $89 \mathrm{~mm}$ /day for $10 \%$ wet period. Duration of $90 \%$ period is about 4 months (129 days) which 
Table 1. Mean and $C V(\%)$ of the parameters (starting date, duration in days and rainfall intensity in mm/day) of five wet periods over eight river basins in India.

\begin{tabular}{|c|c|c|c|c|c|c|c|c|c|}
\hline \multicolumn{2}{|c|}{ River basins } & \multicolumn{2}{|c|}{ Indus basin } & \multicolumn{2}{|c|}{ Ganga basin } & \multicolumn{2}{|c|}{ Brahmaputra basin } & \multicolumn{2}{|c|}{ Narmada-Tapi basins } \\
\hline Wet period & Parameter & Mean & $\mathrm{CV}$ & Mean & $\mathrm{CV}$ & Mean & $\mathrm{CV}$ & Mean & $\mathrm{CV}$ \\
\hline \multirow[t]{3}{*}{$10 \%$} & Start & 21 July & 14 & 9 August & 4 & 7 July & 10 & 8 August & 6 \\
\hline & Duration & 1.5 & 39 & 2 & 33 & 6 & 21 & 1.2 & 37 \\
\hline & Intensity & 38 & 27 & 60 & 9 & 52 & 23 & 65 & 21 \\
\hline \multirow[t]{3}{*}{$25 \%$} & Start & 17 July & 12 & 1 August & 4 & 24 June & 8 & 2 August & 5 \\
\hline & Duration & 11 & 27 & 11 & 16 & 28 & 13 & 10 & 26 \\
\hline & Intensity & 24 & 48 & 30 & 14 & 25 & 19 & 34 & 38 \\
\hline \multirow[t]{3}{*}{$50 \%$} & Start & 1 July & 11 & 18 July & 4 & 5 June & 7 & 16 July & 5 \\
\hline & Duration & 47 & 25 & 39 & 11 & 73 & 9 & 38 & 18 \\
\hline & Intensity & 9 & 43 & 15 & 11 & 18 & 15 & 16 & 23 \\
\hline \multirow[t]{3}{*}{$75 \%$} & Start & 24 May & 19 & 28 June & 4 & 11 May & 8 & 28 June & 4 \\
\hline & Duration & 106 & 24 & 76 & 12 & 131 & 7 & 73 & 13 \\
\hline & Intensity & 5 & 31 & 11 & 12 & 15 & 14 & 12 & 16 \\
\hline \multirow[t]{3}{*}{$90 \%$} & Start & 22 March & 37 & 27 May & 12 & 9 April & 10 & 12 June & 6 \\
\hline & Duration & 186 & 17 & 125 & 16 & 184 & 5 & 112 & 18 \\
\hline & Intensity & 3 & 28 & 8 & 16 & 12 & 13 & 9 & 22 \\
\hline
\end{tabular}

\begin{tabular}{|c|c|c|c|c|c|c|c|c|c|}
\hline \multicolumn{2}{|c|}{ River basins } & \multicolumn{2}{|c|}{$\begin{array}{c}\text { Godavari-Mahanadi } \\
\text { basins } \\
\end{array}$} & \multicolumn{2}{|c|}{ Krishna basin } & \multicolumn{2}{|c|}{ West Coast basins } & \multicolumn{2}{|c|}{ Peninsular basins } \\
\hline Wet period & Parameter & Mean & $\mathrm{CV}$ & Mean & $\mathrm{CV}$ & Mean & $\mathrm{CV}$ & Mean & $\mathrm{CV}$ \\
\hline \multirow[t]{3}{*}{$10 \%$} & Start & 9 August & 5 & 27 August & 6 & 14 July & 6 & 23 September & 9 \\
\hline & Duration & 2 & 25 & 2 & 34 & 3 & 19 & 2 & 24 \\
\hline & Intensity & 58 & 13 & 44 & 15 & 89 & 17 & 50 & 17 \\
\hline \multirow[t]{3}{*}{$25 \%$} & Start & 30 July & 4 & 21 August & 7 & 7 July & 5 & 21 September & 6 \\
\hline & Duration & 16 & 15 & 13 & 24 & 15 & 16 & 16 & 18 \\
\hline & Intensity & 24 & 16 & 20 & 27 & 55 & 18 & 22 & 31 \\
\hline \multirow[t]{3}{*}{$50 \%$} & Start & 12 July & 3 & 28 July & 8 & 23 June & 5 & 29 August & 7 \\
\hline & Duration & 50 & 10 & 54 & 15 & 45 & 14 & 62 & 13 \\
\hline & Intensity & 14 & 11 & 9 & 20 & 36 & 18 & 9 & 20 \\
\hline \multirow[t]{3}{*}{$75 \%$} & Start & 22 June & 3 & 23 June & 7 & 12 June & 4 & 30 June & 12 \\
\hline & Duration & 91 & 9 & 107 & 11 & 86 & 10 & 137 & 12 \\
\hline & Intensity & 11 & 12 & 6 & 18 & 28 & 16 & 6 & 19 \\
\hline \multirow[t]{3}{*}{$90 \%$} & Start & 27 May & 8 & 25 May & 6 & 30 May & 5 & 6 May & 18 \\
\hline & Duration & 138 & 12 & 152 & 10 & 129 & 7 & 199 & 10 \\
\hline & Intensity & 9 & 16 & 5 & 18 & 22 & 16 & 4 & 17 \\
\hline
\end{tabular}

starts at the end of May and coincides with the general onset date of monsoon in this region. Depressions/storms over the the Bay of Bengal strengthen the westerlies which cause deepening of the off-shore trough and thus causing heavy-to-very heavy rainfall along the West Coast.

Decreasing trends have been observed, from figure $3(\mathrm{~g})$, in the rainfall intensities of 50 and $75 \%$ wet periods. In the case of $50 \%$ wet period the trend is significant at 5\% level. Changes in the number of monsoon depressions/storms over Bay of Bengal appears to be the main cause of decline in rainfall intensity along the West Coast.

\subsubsection{Peninsular river basins}

The $10 \%$ wet period occurs in the month of September which is late compared to all other basins in India. On an average, 2 days are sufficient for $10 \%$ contribution to the annual rainfall. The wet period, contributing $50 \%$ to annual, starts in July in all the river basins, except peninsular river basins, where it starts in September as it is dominated by northeast monsoon. The peninsular river basins get rainfall from summer monsoon circulation as well as from northeast monsoon circulation. Chief distinctive features of the wet periods of these river basins, are the late start 

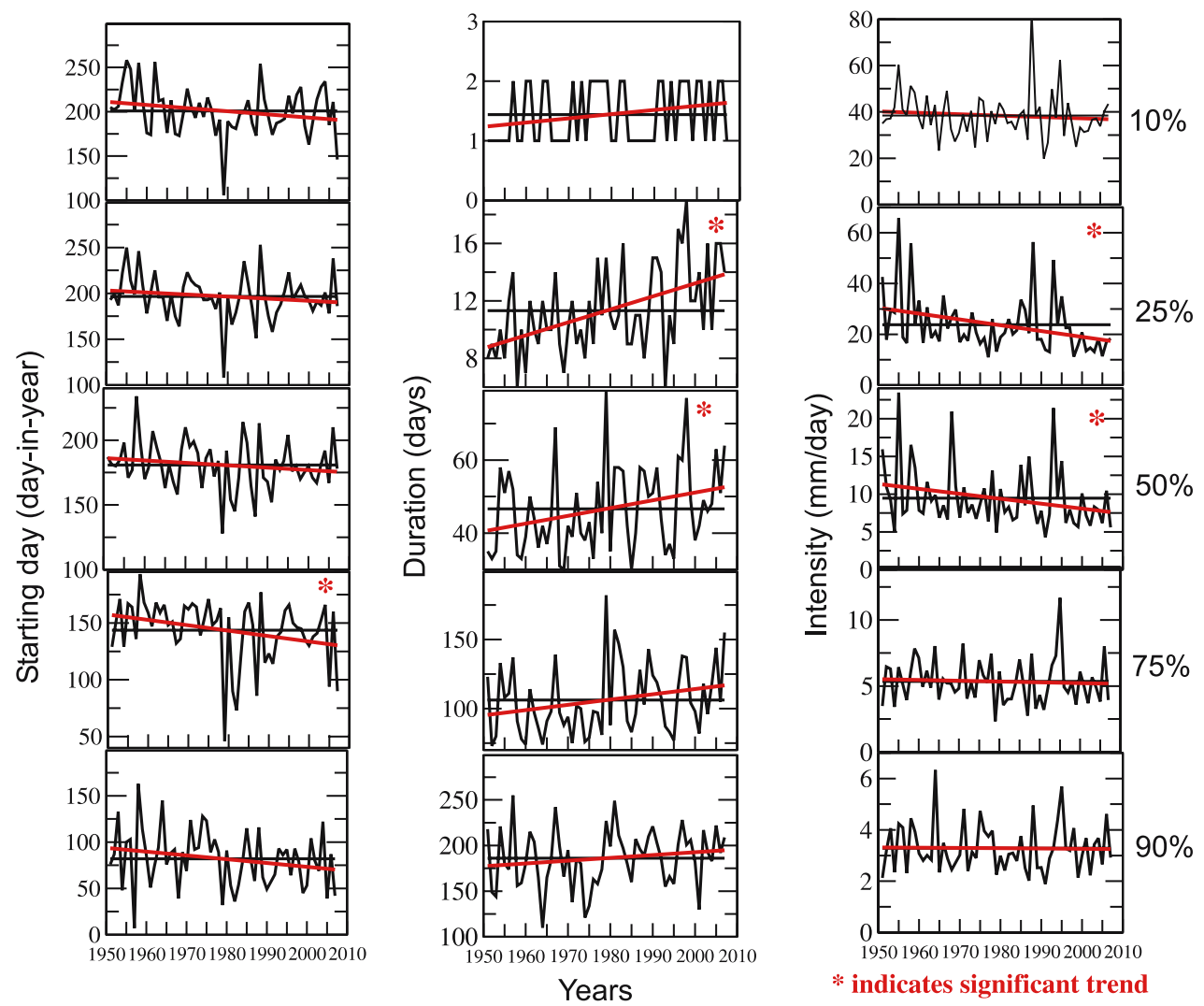

Figure 3(a). Time series plots and linear trends of the wet period parameters for the Indus basin (south of $32^{\circ} \mathrm{N}$ ).
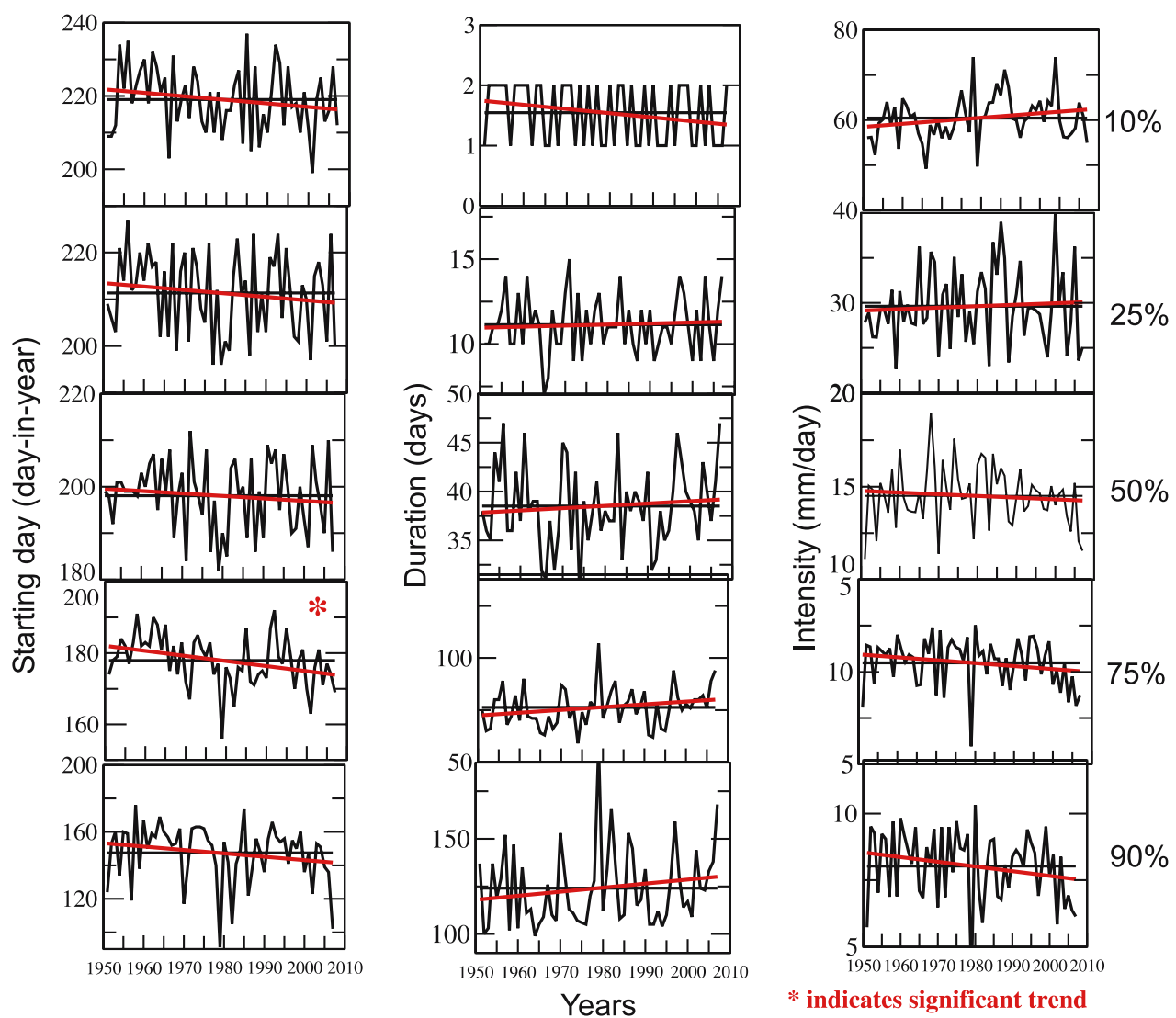

Figure 3(b). Time series plots and linear trends of the wet period parameters for the Ganga basin. 

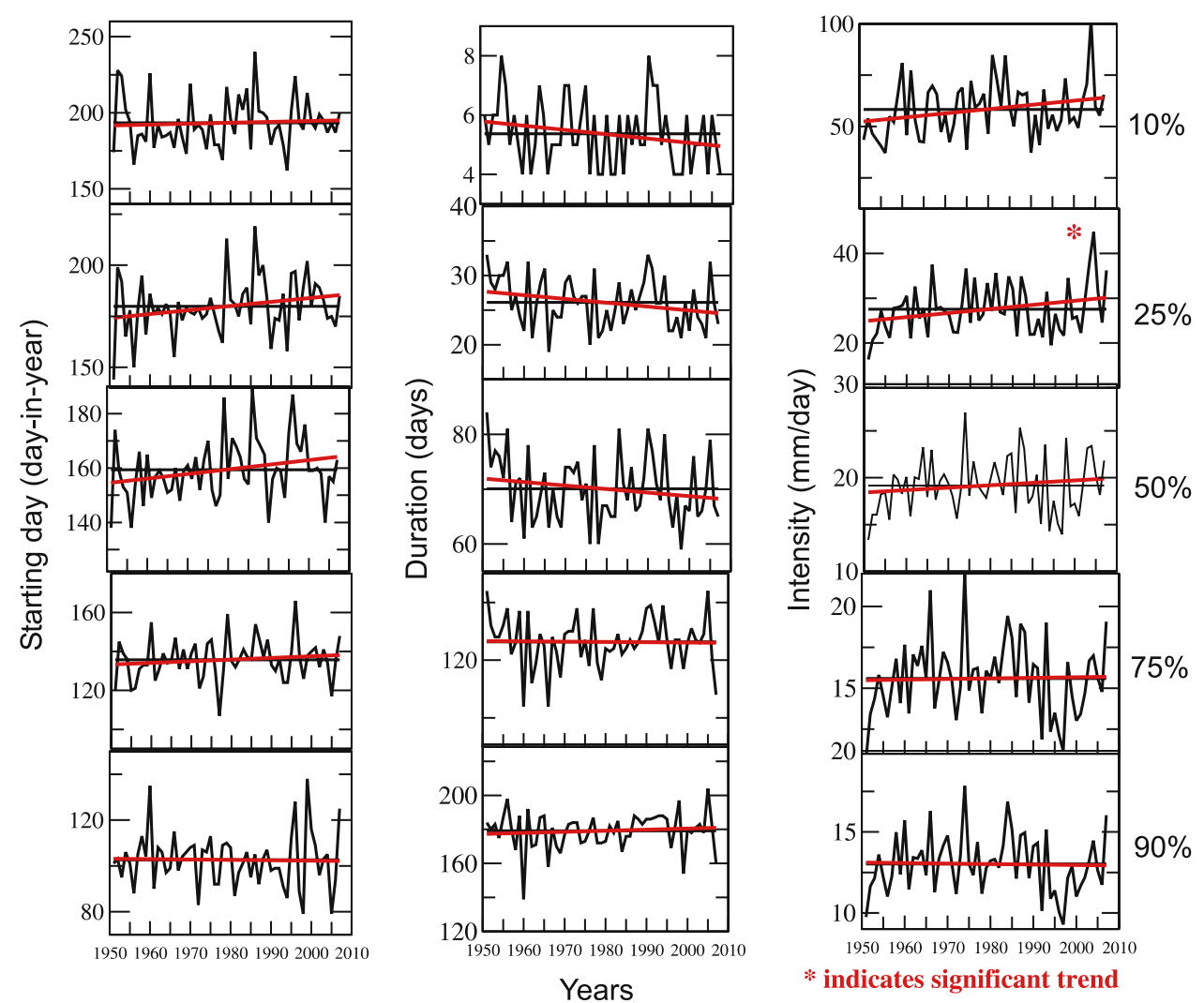

Figure 3(c). Time series plots and linear trends of the wet period parameters for the Brahmaputra basin.
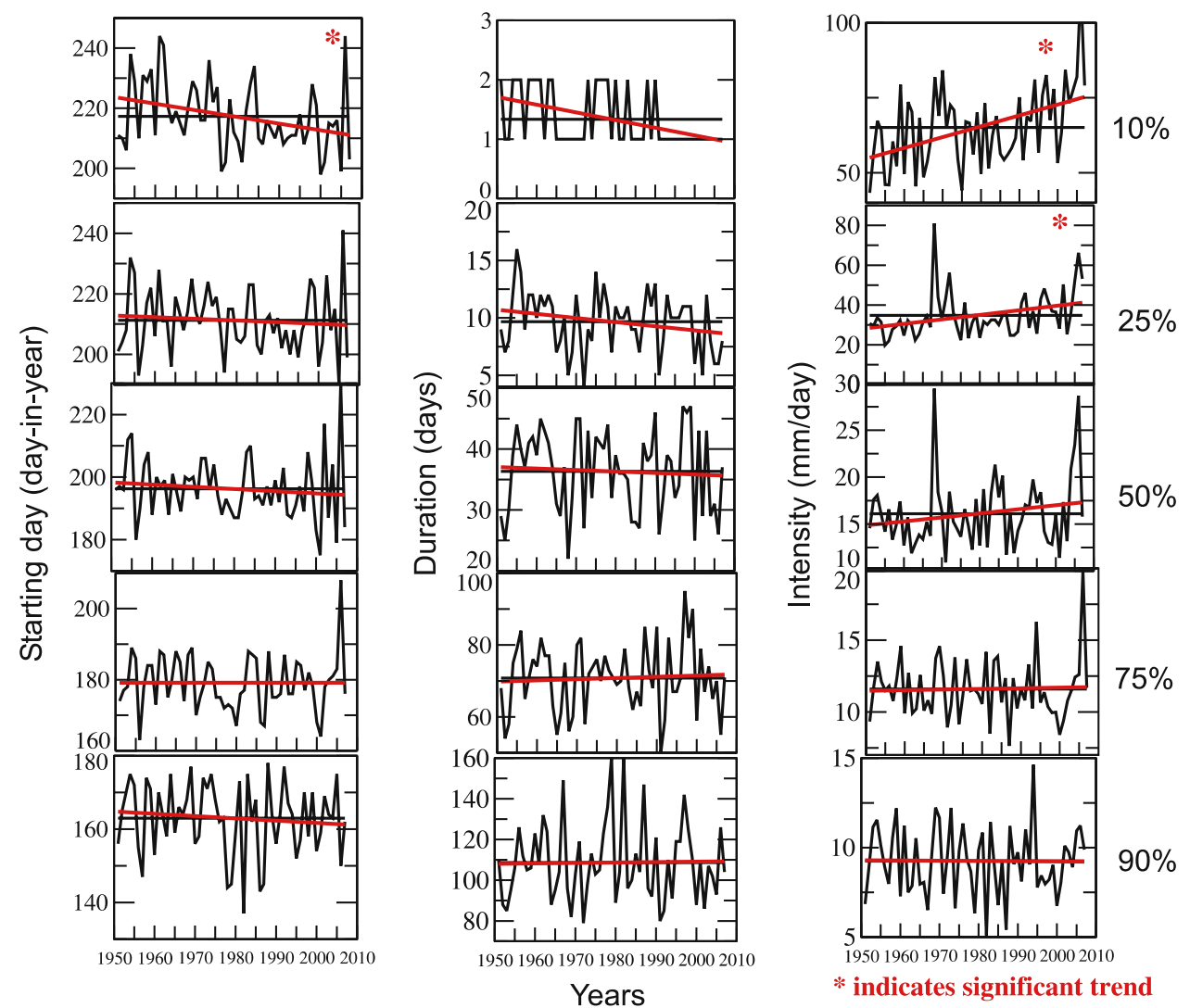

Figure 3(d). Time series plots and linear trends of the wet period parameters for the Narmada-Tapi basins. 

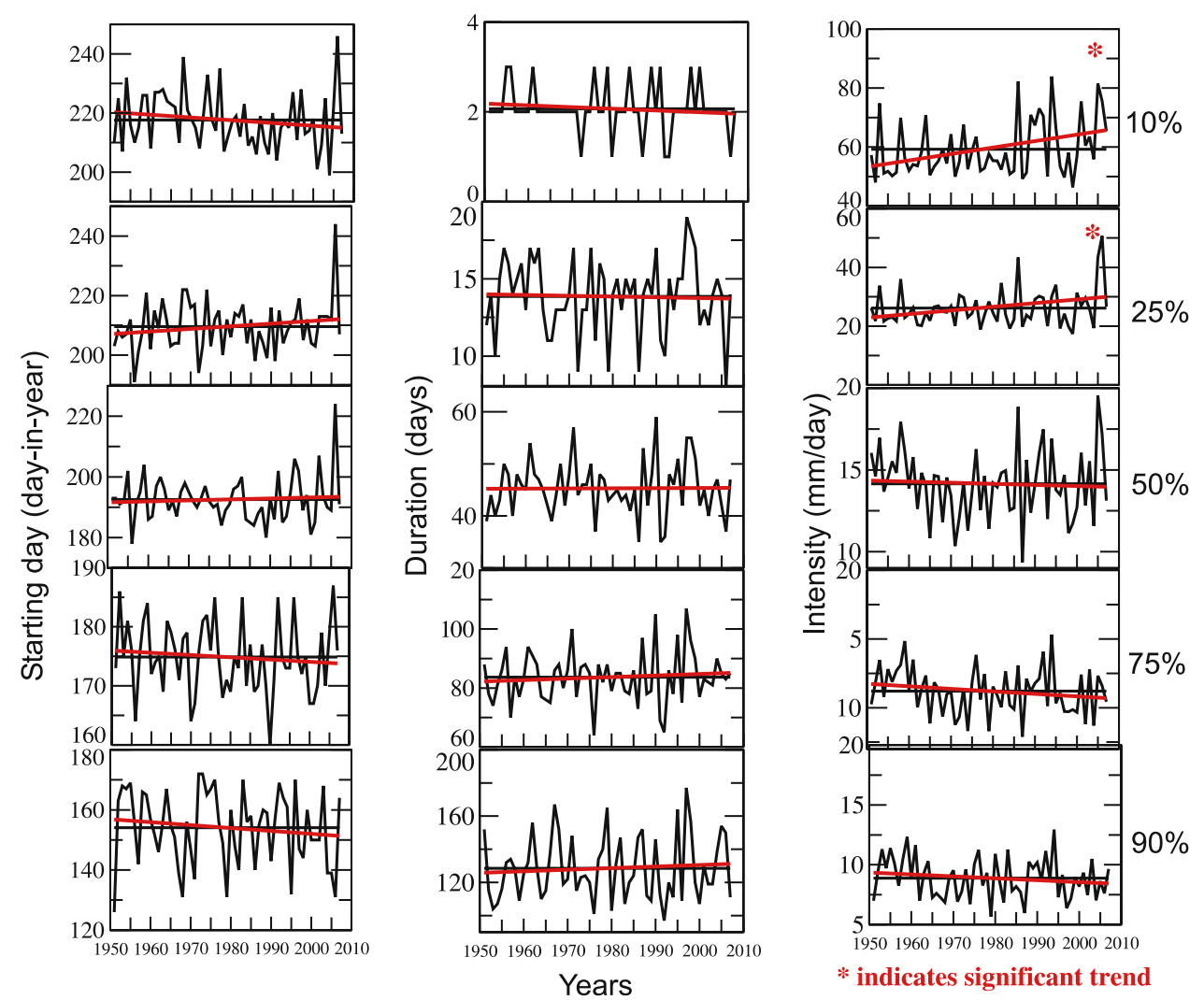

Figure 3(e). Time series plots and linear trends of the wet period parameters for the Godavari-Mahanadi basins.
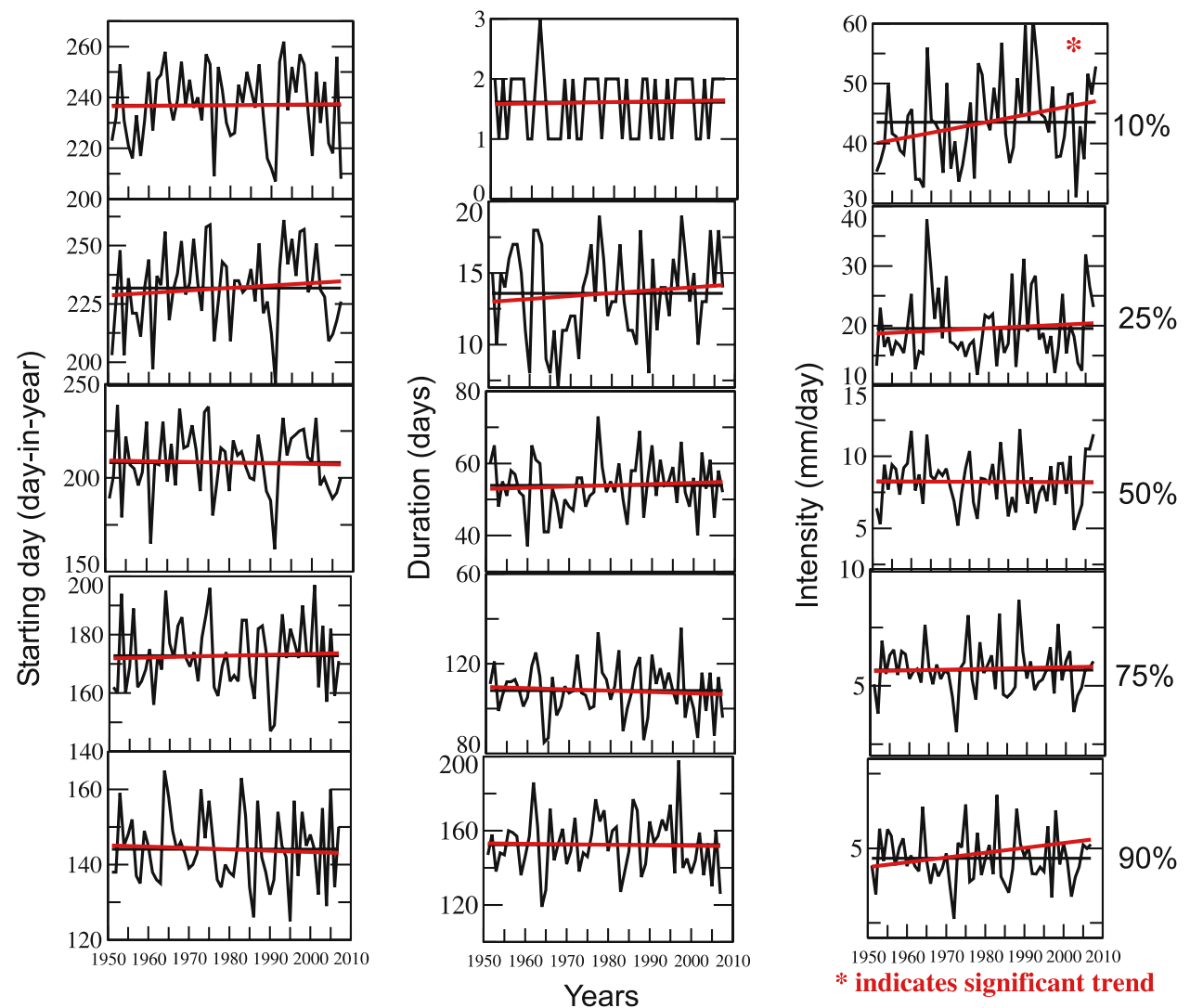

Figure 3(f). Time series plots and linear trends of the wet period parameters for the Krishna basin. 

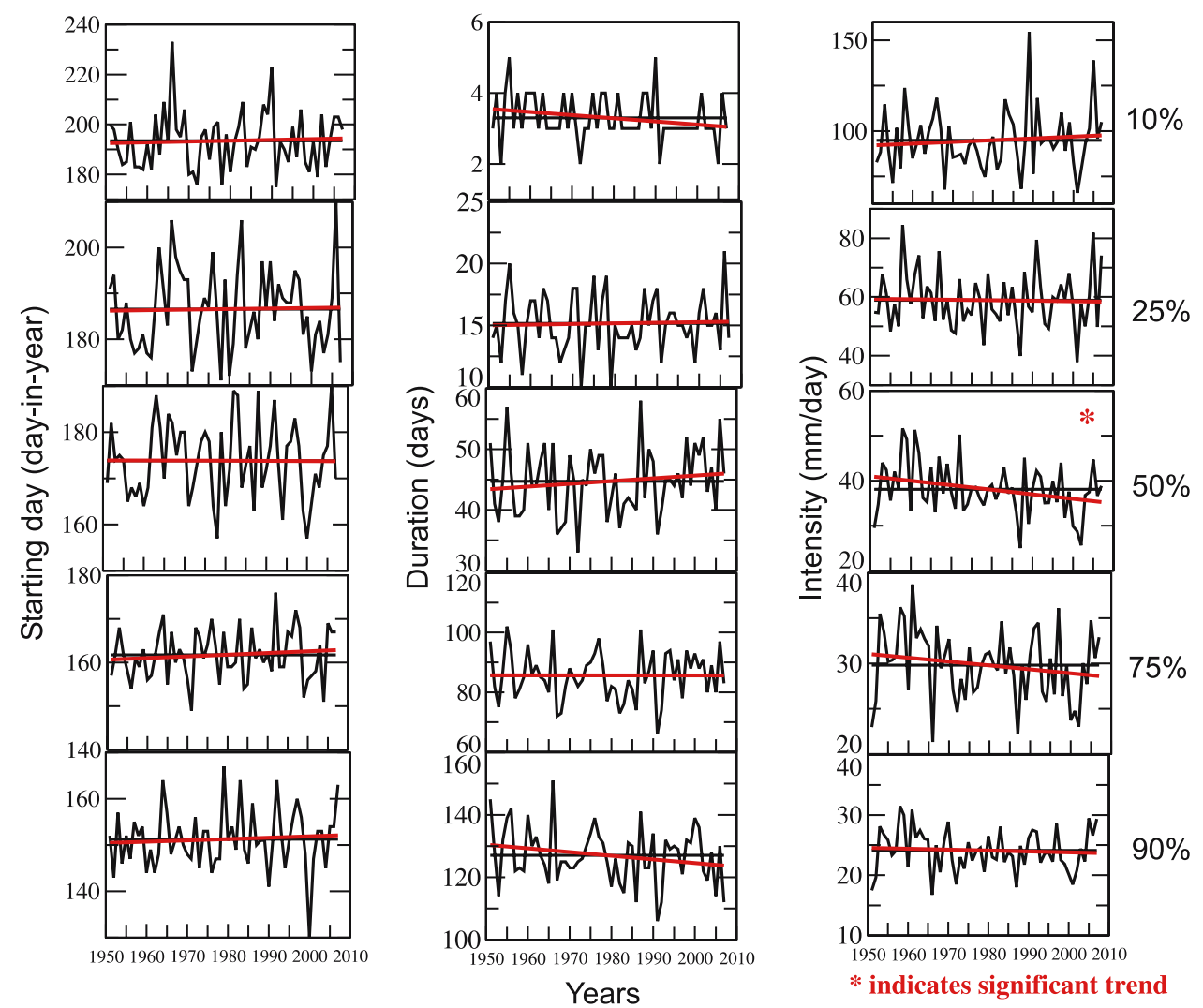

Figure $3(\mathrm{~g})$. Time series plots and linear trends of the wet period parameters for the West Coast river basins.
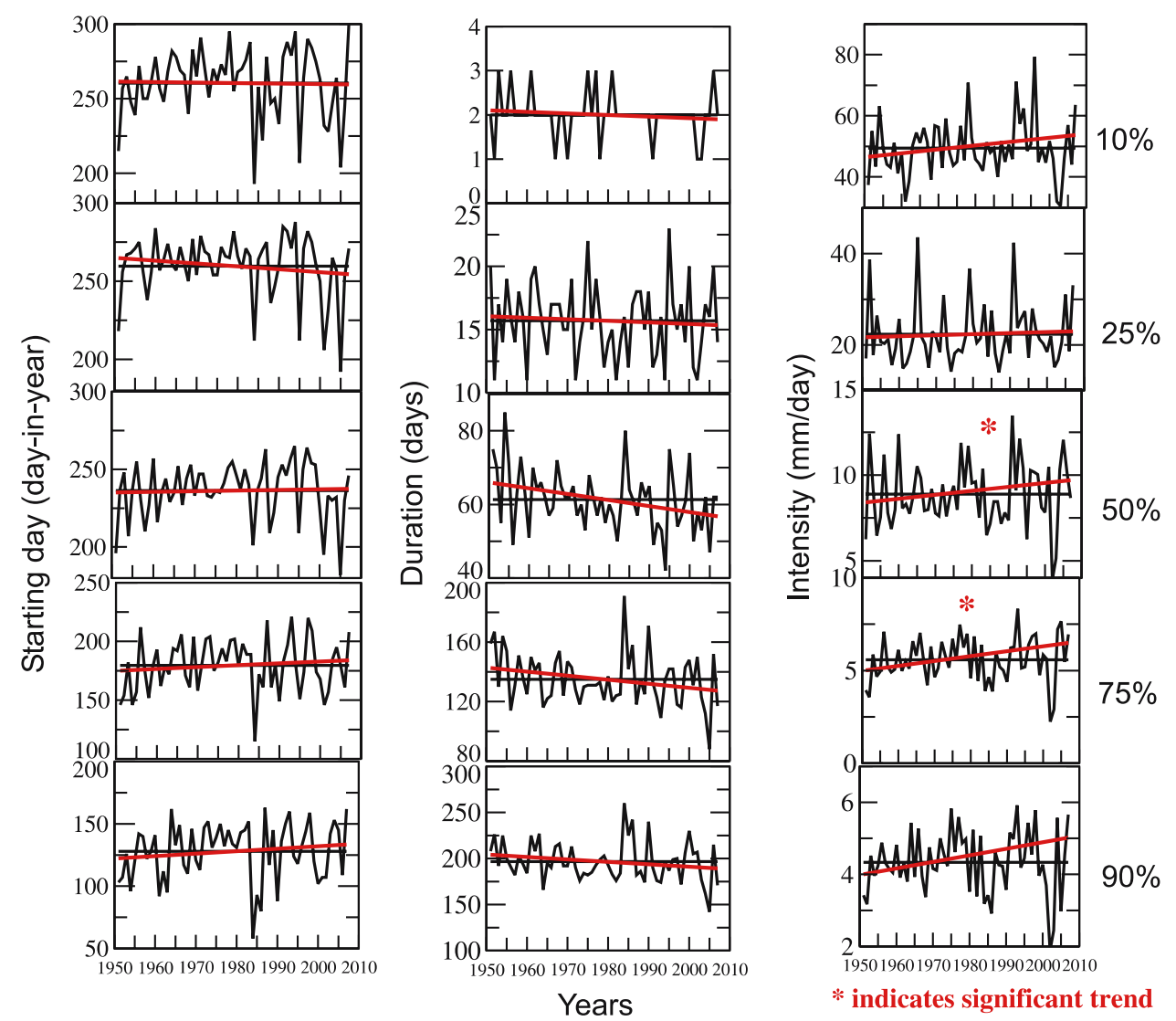

Figure 3(h). Time series plots and linear trends of the wet period parameters for the peninsular river basins. 

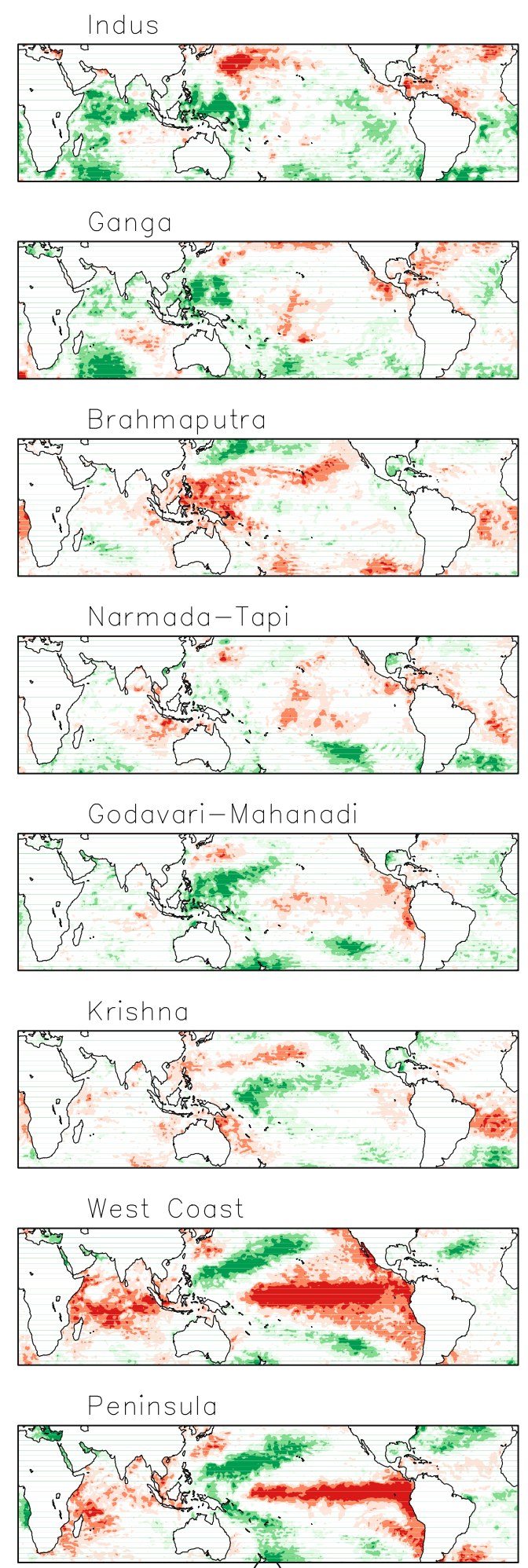

(a)
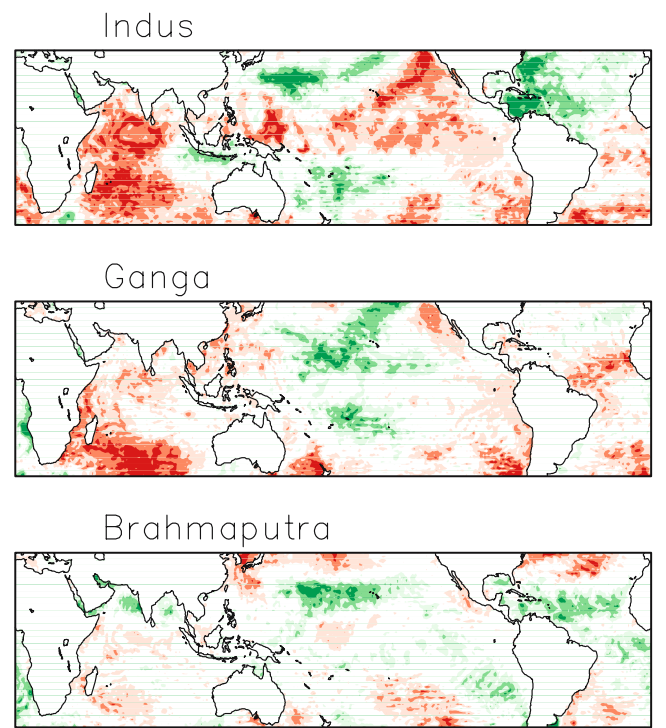

0.3

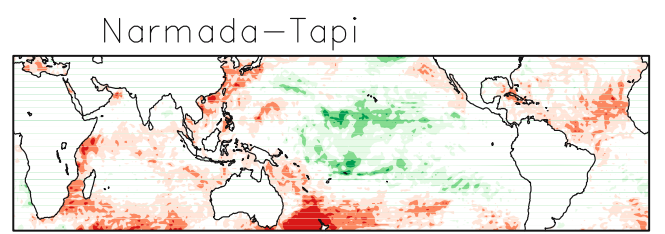

0.2

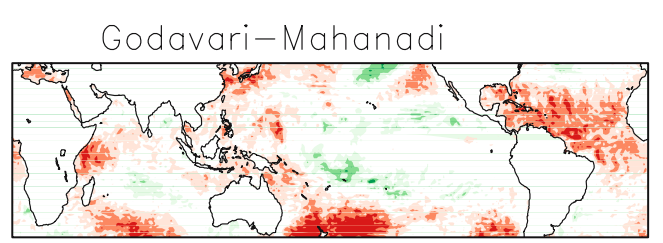

$-0.1$
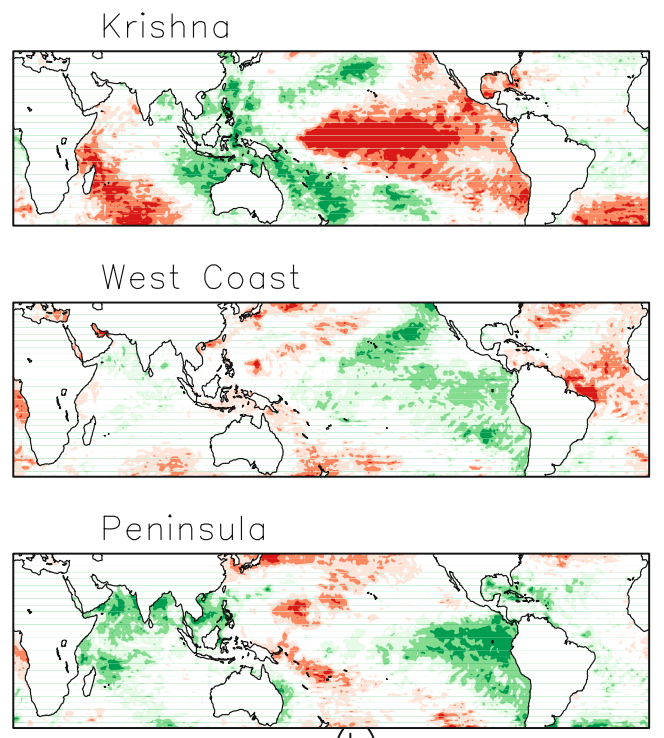

(b)

Figure 4. Spatial patterns of significant correlations between (a) $75 \%$ start and global SSTs (MAM) and (b) duration of $75 \%$ and global SSTs (JJAS).

of the different wet periods in comparison to the rest of the river basins under study, except for $90 \%$ duration. This is due to thunderstorm activity prevailing over the southern tip of India before the onset of monsoon rainfall. Duration for the $90 \%$ period is more than 6 months (199 days) starting from 6 May. Rainfall intensity is the lowest for almost all the wet periods. 

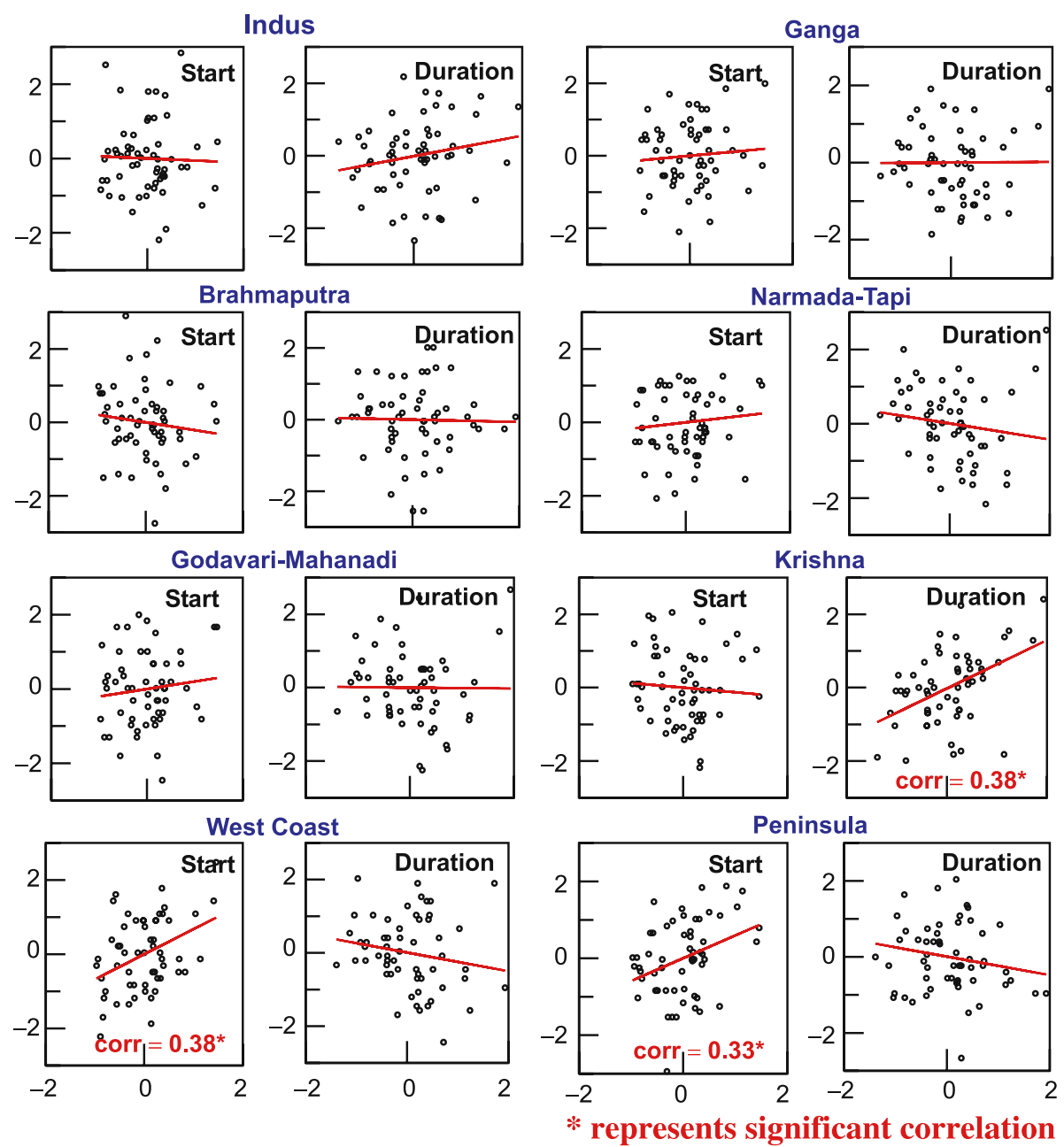

Figure 5. Scatter plots of anomalies of $75 \%$ start vs. Nino 3.4 SST (MAM) and $75 \%$ duration vs. Nino 3.4 SST (JJAS).

Decreasing trends in durations (significant for 50 and $75 \%$ ) and increase in the rainfall intensity are the features of the wet periods over the peninsular river basins (figure $3 \mathrm{~h}$ ).

\subsection{Role of global SSTs in the occurrences of wet spells}

An attempt is made here to assess the association between global SSTs and occurrences of the wet periods such as the start and duration of the wet periods. Southwest monsoon season accounting for $75 \%$ to annual rainfall, is a crucial season for water resources studies in India, hence, only wet periods contributing $75 \%$ to the annual rainfall total, have been considered for the impact assessment studies.

\subsubsection{Spatial patterns of correlations between start and duration of $75 \%$ wet period}

It is seen from table 1 that $75 \%$ wet period starts around June in most of the major river basins in central India. Therefore, for impact assessment studies, SSTs (MAM) are correlated with start of $75 \%$ wet period and SSTs (concurrent JJAS) have been correlated with duration of $75 \%$ wet period over eight river basins. MAM season hints at the potential prediction signal while JJAS tells us the concurrent links between SST variations and the interannual variability of wet period parameters. Spatial patterns of the correlations are shown in figure $4(\mathrm{a}$ and $\mathrm{b})$.

From figure 4(a), it is seen that, equatorial east and central Pacific SST (MAM) are positively correlated (statistically significant), with the start of $75 \%$ wet period for the West Coast and peninsular river basins, indicating increase in SST (MAM) in eastern and central Pacific, results in the late arrival of the $75 \%$ wet period along the West Coast as well as in peninsular India. Indian Ocean SSTs in the season (MAM) seem to be insignificantly correlated with the starting day of $75 \%$ wet period over most of the river basins in India.

Figure 4(b) indicates that duration of $75 \%$ wet period in the Krishna basin is positively correlated with eastern equatorial Pacific SSTs while other 
river basins do not show any association between $75 \%$ duration and global SSTs. It is also seen from the figure that the association of occurrence of wet period is more with equatorial Pacific Ocean SSTs than that of Indian Ocean.

\subsubsection{Scatter plots of starting day and duration of $75 \%$ wet period vs. Nino 3.4 SSTs}

From figure 4(a and b), it is clear that SSTs from Nino 3.4 region $\left(120^{\circ} \mathrm{W}-170^{\circ} \mathrm{W}\right.$ and $\left.5^{\circ} \mathrm{S}-5^{\circ} \mathrm{N}\right)$ have influence on the occurrence of the wet periods $(75 \%)$. Figure 5 shows scatter plots of start and duration of $75 \%$ wet period and SST anomalies from Nino 3.4 region, which is generally used as an index for assessing the intensity of El Niño events.

From figure 5, it is seen that the start of $75 \%$ wet period along the West Coast and in peninsular river basins are positively correlated with Nino 3.4 SSTs indicating that an increase in equatorial central Pacific SSTs results in delaying of the start of the wet period over the West Coast and in peninsular river basins. Duration of the $75 \%$ wet period over the Krishna basin is positively correlated (significant) with Nino 3.4 SSTs of concurrent (JJAS) season, indicating that an increase in SSTs causes an increase in the duration of wet periods of the Krishna basin. No significant association has been observed in the case of parameters of other river basins.

\section{Conclusions}

Spatial and temporal variations of the parameters (starting date, ending date, duration and rainfall intensity) of five wet periods are reported here for the eight major river basins with well-defined drainage pattern. In general, the starting date of the $10 \%$ wet period occurs in July-August, except for peninsular river basins of India. On an average, 1 to 3 days are sufficient to contribute $10 \%$ to the annual rainfall in almost all the river basins, with rainfall intensity varying from $44 \mathrm{~mm} /$ day in the Krishna basin to $89 \mathrm{~mm} /$ day in the West Coast river basins. The $90 \%$ wet period starts in April/June and ends in September/December. The duration of the wet period contributing $90 \%$ to the annual rainfall varies from 112 days in the Narmada-Tapi river basins located in the central parts of India to 186 days in the Indus river basin. The average rainfall intensity of this wet period varies from 5 to $12 \mathrm{~mm} /$ day for all the river basins in India except the West Coast river basins, where it is observed around $22 \mathrm{~mm} /$ day. Trend analysis of wet periods over the southern parts of the Indus basin indicated early occurrences of $75 \%$ wet periods in recent years and increase in the duration of 25 and $50 \%$ wet periods. Most of the river basins in central India showed significant increase in the rainfall intensity of 10 and $25 \%$ wet periods. Association of occurrence of wet period is more with equatorial Pacific Ocean SSTs than with Indian Ocean. The start of $75 \%$ wet period along the West Coast and in peninsular river basins are positively correlated with Nino 3.4 SSTs, while duration of the $75 \%$ wet period over the Krishna basin is positively correlated (significant) with Nino 3.4 SSTs of concurrent (JJAS) season. Such information can be used in qualitative forecasting of onset as well as length of the rainy period over the respective river basins.

\section{Acknowledgements}

The authors are extremely grateful to the Director of the Institute for his constant encouragement and support to pursue this study. Thanks are due to India Meteorological Department (IMD), Pune, India for permitting us to use the daily rainfall data. The authors are also grateful to the anonymous reviewers who have helped to improve the quality of this manuscript.

\section{References}

Ananthakrishnan R and Soman M K 1988 Onset of southwest monsoon over Kerala, 1901-1980; J. Climate 8 283-296.

Angell J K 1981 Comparison of variations in atmospheric quantities with variations in equatorial eastern Pacific; Mon. Wea. Rev. 109 230-243.

Ashok K, Guan Z and Yamagata T 2001 Impact of the Indian Ocean Dipole on the relationship between the Indian Monsoon rainfall and ENSO; Geophys. Res. Lett. 28 4499-4502.

Ashok K and Saji N H 2007 On the impacts of ENSO and Indian Ocean dipole events on sub-regional Indian summer monsoon rainfall; Natural Hazards $\mathbf{4 2 ( 2 )}$ 10.1007/s11069-006-9091-0.

Flohn H and Fleer H 1975 Climate teleconnections with equatorial Pacific and role of atmosphere/ocean coupling; Atmosphere 13 96-109.

Gadgil S and Gadgil S 2004 The Indian monsoon, GDP and agriculture, Economic and Political Weekly 4887-4895.

Goswami B N and Xavier P K 2005 ENSO control on the South Asian monsoon through the length of the rainy season; Geophys. Res. Lett. 32 L18717.

Goswami B N, Venugopal V, Sengupta D, Madhusoodanan M S and Xavier P K 2006 Increasing trend of extreme rain events over India in a warming environment; Science 314 1442-1445.

Higgins R W, Yao Y and Wang X L 1997 Influence of the North American monsoon system on the U.S. summer precipitation regime; J. Climate 10 2600-2622.

Joseph P V and Pillai P V 1984 Air-Sea interaction on seasonal scale over north Indian Ocean, Part I: Interannual variations of SST and Indian Monsoon rainfall; Mausam $35323-330$. 
Klein Tank A M G, Peterson T C, Quadir D A, Dorji S, Zou X, Tang H, Santhosh K, Joshi U R, Jaswal A K, Kolli R K, Sikder A, Deshpande N R, Revadekar J V, Yeleuova K, Vandasheva S, Faleyeva M, Gomboluudev P, Budhathoki K P, Hussain A, Afzaal M, Chandrapala L, Anvar H, Amanmurad, Asanova V S, Jones P D, New M G and Spektorman T 2006 Changes in daily temperature and precipitation extremes in central and south Asia; J. Geophys. Res. 111 (D16105), doi:10.1029/2005JD006316.

Kousky V E 1988 Pentad outgoing longwave radiation climatology for the South American sector; Rev. Bras. Meteor. 3 217-231.

Kumar K K, Balaji R and Cane M 1999 On the weakening relationship between the Indian monsoon and ENSO; Science $\mathbf{2 8 4}$ No. 5423, 2156-2159.

Kumar K K, Kumar R K, Ashrit R G, Deshpande N R and Hansen J W 2004 Climate impacts on Indian agriculture; Int. J. Climatol. 24(11) 1375-1393.

Maity R, Nagesh Kumar D and Nanjundiah R S 2007 Review of hydroclimatic teleconnection between hydrologic variables and large scale atmospheric circulation patterns with Indian perspective; J. Hydraul. Eng. 13(1) $77-92$.

Marengo J A, Liebmann B, Kousky V E, Filizola N P and Wainer I C 2001 Onset and end of the rainy season in the Brazilian Amazon Basin; J. Climate 14 833-852.

Odekunle T O 2004 Rainfall and the length of the growing season in Nigeria; Int. J. Climatol. 24 467-479.

Odekunle T O 2006 Determining rainy season onset and retreat over Nigeria from precipitation amount and number of rainy days; Theor. Appl. Climatol. $\mathbf{8 3}$ 193-201.
Qian W and Yang S 2000 Onset of the regional monsoon over Southeast Asia; Meteor. Atmos. Phys. 75 29-38.

Rajeevan M, Gadgil S and Bhate J 2008 Active and break spells of the Indian summer monsoon; NCC Research Report Nor/2008, 45 pp.

Rao K G and Goswami B N 1988 Interannual variations in SST of Arabian Sea and Indian monsoon; A new perspective; Mon. Wea. Rev. 116 558-568.

Rao N G 1997 Interannual variation of monsoon rainfall in Godavari river basin connections with the Southern Oscillations; J. Climate 11 768-771.

Rasmusson E and Carpenter T H 1983 The relationship between equatorial Pacific sea surface temperatures and rainfall over India and Sri Lanka; Mon. Wea. Rev. 111 $517-528$.

Rayner N A, Parker D E, Horton E B, Folland C K, Alexander L V, Rowell D P, Kent E C and Kaplan A 2003 Global analyses of SST and SI and night marine air temp. since late 19th century; J. Geophys. Res. 108(D14) 4407.

Saji N H, Goswami B N, Vinayachandran P N and Yamagata T 1999 A dipole mode in the tropical Indian Ocean; Nature 401 360-363.

Sikka D R 1980 Some aspects of the large scale fluctuations of summer monsoon rainfall over India in relation to fluctuations in the planetary and regional scale circulation parameters; Proc. Indian Acad. Sci.(Earth Planet. Sci.) 89 179-195.

Singh N, Kumar K K and Soman M K 1989 Some features of the periods contributing specified percentages of rainfall to annual total in Kerala, India; Theor. Appl. Climatol. 39 160-170.

Wang B 1994 Climatic regimes of tropical convection and rainfall; J. Climate 7 1109-1118. 